\title{
Political Communication in the Age of Social Media
}

\author{
Ahmad Munardin Hadma ${ }^{a, 1, *}$, Juliardi Dwi Anggoro ${ }^{\text {b,2 }}$ \\ ${ }^{a}$ Universitas Muhammadiyah Buton, Jl. Betoambari, Lanto, Batupoar, Kota Bau-Bau, Sulawesi Tenggara 93724 \\ ${ }^{\mathrm{b}}$ Universitas Muhammadiyah Buton, Jl. Betoambari, Lanto, Batupoar, Kota Bau-Bau, Sulawesi Tenggara 93724 \\ ${ }^{1}$ ahmad_munardin@gmail.com*; ${ }^{2}$ juliardidwi@gmail.com \\ * corresponding author
}

\begin{abstract}
A BSTRA C T
Article history

Received 09-11-2021

Revised 10-11-2021

Accepted 11-11-2021

Keywords

Internet

New Media

Social Media

Political Communication

The development of communication technology has penetrated human life. One form of communication technology development is new media (new media) which then gave birth to social media. The world of politics cannot be separated from the influence of the development of new media and social media. Social media are like two sides of a coin for political actors. On the one hand, the success of using social media can enable political actors to get positive support. But on the other hand, failure to take advantage of social media risks damaging the image he has. This article uses a qualitative approach to discuss the challenges and opportunities of social media for political actors. The explanation of the use of social media in political communication is the first part of this paper. The second part discusses the challenges faced by political actors in this 4.0 era The third part offers an opportunity for political actors to use social media. The fourth or final part is a conclusion that contains what political actors should do to minimize risks and maximize the opportunities offered by social media.
\end{abstract}

This is an open access article under the CC-BY-SA license.

\section{Introduction}

The development of global information and communication technology (ICT) has resulted in the growth of cyber communication, both among the government, socio-political institutions, and among the community. The development of communication communication regarding the use of new media as a medium of communication to create content including blogs, social networks, wikis, forums and virtual worlds. Types of social media that are currently developing and are in great demand are Facebook, Myspace, and Twitter, youtube, etc. If traditional media uses print and broadcast media, then social media uses the internet. Thus, social media as a means of communication has a role in bringing people (users) to participate actively by contributing and giving feedback openly, both to share information and to respond online in a fast time. Social media, like Facebook, at first, tended to be related to friendship issues (Hawali \& Cyrielle, 2020).

However, currently, many have started to touch on the political realm of government or state power. Binder (2000) emphasizes that the development of communication technology has a good effect on the political process. In fact, the advancement of digital communication by email will bring about a new spirit of democracy. 


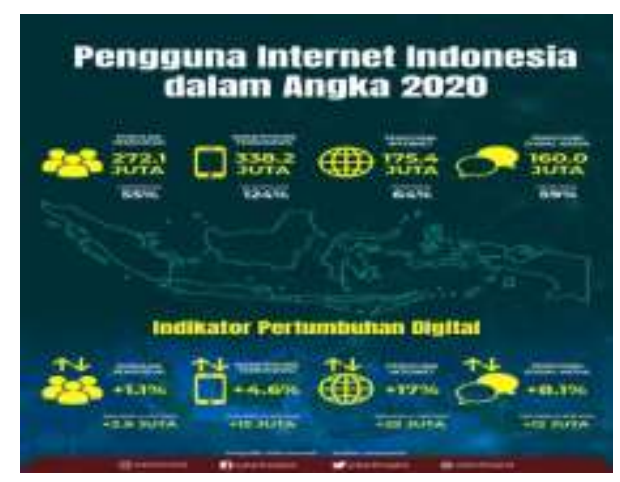

Fig. 1. Internet Users in Indonesia

As in the picture above, the digital growth indicators that occur every day will increase. Digital media opens the space for communication and political participation by increasing the possibility of interaction between important elements in it, namely parties and state institutions known as elites and citizens or non-elites. Many political parties in Indonesia already have Facebook, Twitter, and YouTube accounts, in addition to the official websites of political parties ("Political Parties Seriously Work on Social Media”, Kompas.com, 20 May 2020) (Romli, 2012).

Meanwhile, politicians each have personal accounts such as the Ministry of Communication and Information (@kemkominfo) Johnny G Plate (@PlateJohnny), Minister of Education Nadiem Anwar Makarim (twitter @ nadiemmakarim). Even the twitter account of the president of the Republic of Indonesia Joko Widodo (@Jokowi) has a verified account status, which means that it has received verification from Twitter. Other politicians with twitter accounts include Prabowo (@ Prabowo08) and Wiranto (@wiranto1947). Work programs, opinions on current issues, or discussions that are light in nature, responding to mentions from the community, are important things generally listed on the political figures' Twitter timelines. Social media does offer opportunities for political actors to be able to attract voters, interact directly with the public as well as form "intimate" conversations with the public. But on the other hand, social media can also make political actors laugh or even scorn from the public. A critical question was asked by Momoc (2018) regarding the benefits of social media in the political realm. Specifically, Momoc discussed the campaign. By targeting an online audience, can the internet help politicians to get large numbers of voters? Will this work if the politician does not have credibility in the real world?

\section{Theorotocal Framework}

\section{1) New Media and Political Efficacy}

The Internet and social media provide an opportunity to the young population for political discussion through various online groups, pages, and accounts. Emphasized on the role of new media for providing the platform for political participation and changing their political efficacy. Schulz, Altman, \& Moher (2010) study suggested that new media users are active in politics and political discourse. The Internet has developed the interests toward politics of its users and improved political efficacy of the respondent which create their online and offline political engagements. Jiang et al., (2019) examined the effects of the Internet on online and offline political participation. He also investigated the Internet's role in molding citizens' perceptions of politics. This strong relationship creates political efficacy and election interest among Internet users and increases their political involvement. The use of the Internet has become the main source of political efficacy and political participation, enhancing awareness about voting and campaigning. New media also increases the ratio of voters' turnout among users. It develops the approach which helps in voting and donating campaign for politics ("Space mission analysis and design," 1992). Users' efficacy helps them to understand the political affairs in a better way through the acquisition of political information from new media. Investigated the youth, new media, and the rise of participatory politics and concluded that new media has given a platform to individuals for information and communication with large audiences and a means to participate in political activities. The abovementioned studies have been conducted in developed countries and shared the similar findings. 
However, marginalized and rural areas youth have been excluded and neglected in the research domain. Our study focuses on rural active youth in political process through social media.

\section{2) New Media and Political Participation}

It is fair claim that social media has its disadvantages too. For instance, Calder (1984)study argued that "it is necessary to know the disadvantages of new media for political communication and we have to save political participation from this situation rather than to accept it" (p. 66). Focused on the usage of online media in political activities among university students. The findings of the study show the relationship of online and offline political participation; however, compared with Facebook, email plays a small role in political discussion. Similarly, examined SNS and political participation and concluded that Facebook content shows a positive response regarding political participation. Gibson \& McAllister (2013) evaluated online social ties and political engagement and examined how online platforms increase political interaction. In addition, online interaction is enhancing similar bonds among unrelated bridging networks; they found that online social contact fosters offline participation. Following the trend in this research domain, Investigated political participation and engagement via different online and offline channels and found that new media and other online channels allow political participants to get involved in politics and express their opinion openly. Individual attitudes vary as do their digital media use and real-life political participation.

The use of Internet and all other e-activities improves the knowledge of online users about politics and spurs political engagement and participation. Cantijoch and his colleagues studied the use of Internet, political engagement, and the impact of e-discussion, e-information, and e-political campaigning. Their findings claimed that e-campaigning directly connects and engages Internet users before and after elections (Gibson \& McAllister, 2013). Robles, Molina, \& De Marco (2012) also observed this political attitudes and engagement in the case of individuals on digital platforms in Spain. Study findings show significance difference between cognitive and effective components of attitude. Rainie, Smith, Schlozman, Brady, and Verba (2012) investigated social media and political engagement and found that $39 \%$ of adults in the United States used social media and one out of every eight adults used social media for civic and political purposes.

Social media generated new trends for political participation and changed the patterns of political communication. Kietzmann, Hermkens, McCarthy, \& Silvestre (2011) endeavored to dig out the facts about social and digital media in political communication and concluded that social media is being used for the purpose of social relations and updating the users about happenings. Analyzed the usage of social media for political communication and found a strong relationship among politicians and social media users. In addition to that, due to SNS, interaction between voters and politicians has improved significantly. Examined the influence of social media in India, on voting behavior, their results show that social media unites people within political parties. revealed that activists used social media for collective action. Examined politicians' social media use to influence constituent perceptions and found that voters responded more positively to politicians' personal content rather than to their professional content. Similarly, discussed Facebook as a unique platform for interaction between political parties and voters; the study provides best practices to link with voters for political engagement. studied social network systems as a tool for political change. Their findings clearly showed that social media was widely used as a communication network among candidates and voters. By providing information about politics, social media invites participation and mobilization and plays a vital role in political education as well as the mobilization of the public in politics (Rousseau, 2018).

According to the latest statistics, Pakistan has 44.61 million Internet users. Among these Internet users, 37 million are considered as active users of social media. Among them, 36 million use Facebook, 6.30 million use Instagram, 1.26 million use Twitter, 2.15 million use Snapchat, and 5.10 million use LinkedIn. Moreover, $41 \%$ users are between 18 and 24 years and $36 \%$ people are between 25 and 34-years-old. These statistics indicate that the majority of social media and Internet users are young people in Pakistan. Another digital marketing company published latest report named Digital Statistical Indicators 2018 and claims that 44.6 million out of 198.9 million are Internet users, which is $22 \%$ of the total population. Out of them, only 35 million are active users of social media, which is $18 \%$ of the total population. Mobile users are 109.5 million out of the total

W: http://journal2.uad.ac.id/index.php/commicast/index |E: commicast@comm.uad.ac.id 
population, and among them, 32 million are active Internet and social media users from their mobile devices, which is just $16 \%$ of the total population. The majority of social media users are the young people both in rural and urban areas.

\section{Method}

This research is a qualitative research. The main objective of qualitative research is to understand (to understand) social phenomena or symptoms by focusing more on a complete picture of the phenomena being studied rather than breaking them down into interrelated variables (Saleh, 2012). In addition, in this study, qualitative data analysis becomes easier and produces more professional results (AlYahmady \& Al Abri, 2013).

\section{Results and Discussion}

The influence of social media in politics, especially in terms of political communication, especially in election campaigns (Budiyono, 2016). It is important for political institutions to actively participate in political communication based on social media, especially in election campaigns. Social media further describes it as an ideal means and information base to find out public opinion about policies and political positions, in addition to building community support for politicians who are campaigning. Numerous studies have shown politicians around the world have adopted social media to build relationships with constituents, engage in direct dialogue with communities and shape political discussion. Ability to create space for dialogue between politicians with the public and attracting young voters / voters make social media even more important for politicians (Budiyono, 2016) Before using social media politicians have used the internet to campaign. The internet can be a potential way to break through the oppressive political democracy of the masses that voice voices from the bottom up, which are often used by the rulers with their power for the benefit of their groups.

The success of using social media is seen as one of the factors in Barack Obama's success in winning the presidential election in the United States. About 30 percent of Obama's campaign messages were delivered through new media (Riaz, 2016). Several years before Obama, there was the name Howard Dean who was able to use the internet to gain US public attention. But at that time Dean ran aground at the Democratic Party national convention (Hsieh, Miguel, Ortega, \& Rodriguez, 2011). What about social media in Indonesia? Social media has indeed begun to be looked at in the last two years. Supporters of Joko Widodo and Basuki Anis Baswenda in the Jakarta gubernatorial election campaign used YouTube to post videos of their creative campaigns, and used Instagram, Facebook, Twitter to post their profiles and performances as political actors to increase their competitiveness in the campaign. There was even an online game that had a storyline like the Angry Birds game, with the main character Jokowi.

\section{a. Social Media Challenges for Political Actors}

In the previous section, it was explained that social media is still not being used properly by political actors in Indonesia. The first challenge is the loss of the boundaries of social status in the world of social media. According to Rush \& Et.al., (2000) in computer-mediated communication, communication participants will get wider equality of participation than face-to-face. This opinion indeed refers to communication activities within the organization. However, it is relevant if it is brought into the context of political communication in the era of social media. With the existence of social media, political actors must also realize that even though they are in real terms a high official or a ruling political party, their position on social media will be equal to other users. Therefore, political actors must be prepared to face criticism (some of them even tend to be scathing) by other users. Social media is a jungle, and there are practically no rules in it (Gasarah \& Aye, 2015). If these challenges are not handled wisely, the result is that these political actors will actually become the subject of scorn in cyberspace. It is quite popular to report how the First Lady has been involved in debates several times and it is about non-substantive matters with other users on Instagram.

Apart from that, political actors can no longer use social media as a means to "vent". In the digital interactive era, the production of political messages and images is prone to being "disturbed". 
Political actors must consider the possibility that their messages will be modified by other parties when the message is conveyed via social media. The digital media environment does not value the integrity of information: once the information is published online, anyone is free to modify it (Fadillah, 2017). Internet users are not interested in looking for track records or programs offered by politicians. On the other hand, there is a tendency during the election campaign period, the internet is actually used to make fun of politicians and attack politicians who are not liked.

\section{b. Social Media as a Branding Tool: An Offer}

The weakness of political parties and politicians in Indonesia is that they only "greet" regular constituents / regular supporters every five years, namely before the general election. If it is not approaching general elections, parties or politicians only greet supporters the rich (Hawali \& Cyrielle, 2020). Even though ordinary people also need to be greeted. In the branding process to the community, various ways are needed so that the delivery of messages can be effectively embedded in the minds of the public. One way that is currently considered effective and efficient is through the use of new media. By relying on the ability of the internet to spread messages many to many, these personal figures can quickly feel the positive effects of new media. Branding using new media represented by social media can have a positive effect on companies and in cases this is personal. This is supported by the ability of the internet to reach people who were previously neglected through old branding. This research is also complemented by the ability of social media which they can use in their daily livesthe language of the people so that the quality of the message can spread widely to the public The success of branding through social media is determined by managing social media in an up to date manner and maintaining consistent communication using the structure of conversations that are developing in the community (Gazali, 2004).

Maintaining social media management that is always up to date and serving the public in providing information is not easy. Consistency is a key word that all parties need to understand. In addition, politicians also face other challenges related to the use of social media as an effort to form branding, namely presenting themselves in accordance with the expectations of the community (Tabroni, 2012). Based on growing research, the use of social media has several strategic advantages. Broadly speaking, the benefits generated from branding using internet-based media are easy, cheap, practical, and effective. The price that must be paid is also a major consideration in using social media as a branding tool. It is enough to optimize the role of features in social media, then the message will automatically arrive in the minds of the people. Only with the power of the internet one message can spread to many parties, according to the nature of the internet, namely many to many. However, there are still many political figures who put forward old fashion branding with the installation of baleho, banners, and posters that highlight the abilities and advantages offered by him if elected. This is because many political figures still believe that voters living in remote areas are not proficient and do not understand the use of the internet. Imagine the use of social media, how much can you save .

The cost of installing banners and the like can be minimized by being careful and diligent in providing information on social media. Practicality is also a distinct advantage, the nature of branding is quite practical because it can reach all groups, without the need to divide residents. It is quite practical when compared to old fashion branding which has to break the concentration and the type of message that will be conveyed to the upper class, middle class, and lower class who cannot afford it. However with The number of social media users in Indonesia, which reaches 75 million, is clearly a more practical way if branding is focused on the use of social media. However, in terms of effectiveness, it cannot be seen with precision, because the focus of this study is not the effectiveness of branding using social media. The effectiveness can only be measured after the election of these political figures. However, from the many studies and examples of case studies that have occurred in the field, it can be seen that the use of social media as a means of branding can run smoothly. Taking the example of a case study on the 2012 Jakarta gubernatorial election, which passed Jokowi Ahok the winner. The campaign process until the branding they run uses a lot of assistance from social media such as Facebook, Twitter, and YouTube. So it is not wrong if there is a possibility that branding carried out with social media can reap positive results (Peters, Chen, Kaplan, Ognibeni, \& Pauwels, 2013).

W: http://journal2.uad.ac.id/index.php/commicast/index |E: commicast@comm.uad.ac.id 


\section{Conclusion}

A certain success team of political figures is too hasty and fast in conveying messages via social media without paying attention to certain rules. Sometimes it's just a matter of quantity of messages that are considered regardless of the quality or content of the message. Self-campaign or branding delivered through messages on social media must match the desires and target audience. Like twitter, path, and facebook, messages that are conveyed must have a language that is in line with each target audience. Lifestyle or lifestyle is also one way to enter and quickly adapt to the audience. By displaying a message that is currently trending, a message will quickly enter the mind of the audience. We take the example of the use of the You Tube video "One Direction Parody" which is intended to elect Jokowi for the new Jakarta. The video, which has been watched by 10 million people, clearly represents the lifestyle of the younger generation as new voters. The three main keys are: Unique videos (parodies), songs belonging to the rising boy band One Direction, and You Tube. social media in conveying messages in other ways, not only in writing to the audience. While the different messages offered are through unique videos, where the average YouTube user is more interested in opening YouTube to browse unique and funny videos. Parodies that are characteristic of early 2000s Indonesian comedy are highlighted in the form of the most popular songs and music of the time Meanwhile, One Direction with its song Someone you loved has become the most popular and sought after song throughout 2020. So that the steps taken by Jokowi's success team by comparing through parody songs on Youtube became one of the important turning points in Jokowi's victory.

\section{References}

AlYahmady, H. H., \& Al Abri, S. S. (2013). Using Nvivo for Data Analysis in Qualitative Research. International Interdisciplinary Journal of Education. https://doi.org/10.12816/0002914

Binder, K. (2000). Introductory Statistical Mechanics. European Journal of Physics. https://doi.org/10.1088/0143-0807/21/2/701

Budiyono, M. (2016). MEDIA SOSIAL DAN KOMUNIKASI POLITIK: MEDIA SOSIAL SEBAGAI KOMUNIKASI POLITIK MENJELANG PILKADA DKI JAKARTA 2017. Jurnal Komunikasi. https://doi.org/10.20885/komunikasi.vol11.iss1.art4

Calder, W. A. (1984). Size, function and life history. Book Review.

Fadillah, D. (2017). KOMUNIKASI POLITIK ANTAR KOALISI PARLEMEN DI DPR RI. CHANNEL: Jurnal Komunikasi, 5(1). https://doi.org/10.12928/channel.v5i1.6357

Gasarah, F., \& Aye, G. (2015). Effect of Household Endowment on Fertilizer Use in Rice Production in Kwande, Benue State, Nigeria. Asian Journal of Agricultural Extension, Economics \& Sociology. https://doi.org/10.9734/ajaees/2015/12272

Gazali, E. (2004). Interaksi Politik dan Media : Dari Komunikasi Politik ke Politik Komunikasi. Jurnal Ilmu Sosial Dan Ilmu Politik.

Gibson, R. K., \& McAllister, I. (2013). Online Social Ties and Political Engagement. Journal of Information Technology and Politics. https://doi.org/10.1080/19331681.2012.712461

Hawali, B. G. M., \& Cyrielle, D. (2020). Review of mass media effect in inter-cultural communication. International Journal of Communication and Society, 2(2), 94-101. https://doi.org/10.31763/ijcs.v2i2.153

Hsieh, C. T., Miguel, E., Ortega, D., \& Rodriguez, F. (2011). The price of political opposition: Evidence from Venezuela's Maisanta. American Economic Journal: Applied Economics. https://doi.org/10.1257/app.3.2.196

Jiang, Y. Z., Ma, D., Suo, C., Shi, J., Xue, M., Hu, X., ... Shao, Z. M. (2019). Genomic and Transcriptomic Landscape of Triple-Negative Breast Cancers: Subtypes and Treatment Strategies. Cancer Cell. https://doi.org/10.1016/j.ccell.2019.02.001

Kietzmann, J. H., Hermkens, K., McCarthy, I. P., \& Silvestre, B. S. (2011). Social media? Get serious! Understanding the functional building blocks of social media. Business Horizons. https://doi.org/10.1016/j.bushor.2011.01.005 
Peters, K., Chen, Y., Kaplan, A. M., Ognibeni, B., \& Pauwels, K. (2013). Social media metrics - A framework and guidelines for managing social media. Journal of Interactive Marketing. https://doi.org/10.1016/j.intmar.2013.09.007

Riaz, S. (2016). High Performance Work Systems and Organizational Performance: An Empirical Study on Manufacturing and Service Organizations in Pakistan. Public Organization Review. https://doi.org/10.1007/s11115-015-0315-1

Robles, J. M., Molina, Ó., \& De Marco, S. (2012). Participación política digital y brecha digital política en España. Un estudio de las desigualdades digitales. Arbor. https://doi.org/10.3989/arbor.2012.756n4012

Romli, A. S. M. (2012). Jurnalistik Online: Panduan Mengelola Media Online . In Jurnalistik Online Panduan Mengelola Media Online .

Rousseau, P. (2018). Doris. Journal of the American Geriatrics Society. https://doi.org/10.1111/jgs.15072

Rush, \& Et.al. (2000). Pengantar Sosiologi Politik. Jakarta: PT Raja Grafindo Persada.

Schulz, K. F., Altman, D. G., \& Moher, D. (2010). CONSORT 2010 Statement. Obstetrics \& Gynecology. https://doi.org/10.1097/aog.0b013e3181d9d421

Space mission analysis and design. (1992). Choice Reviews Online. https://doi.org/10.5860/choice.29-5149

Tabroni, R. (2012). Etika Komunikasi Politik Dalam Ruang Media Massa. Jurnal Ilmu Komunikasi. 